\title{
Espanto e retenção como tonalidades afetivas fundamentais do outro início
}

\author{
Astonishment and retention as fundamental \\ affective tones of the other beginning
}

Leandro Assis Santos

Professor da Faculdade de São Bento - Rio de Janeiro

leandroas30@hotmail.com

\section{Resumo}

Esta pesquisa busca esclarecer alguns contornos de um conceito-experiência central à filosofia de Martin Heidegger: a noção de tonalidade afetiva (Stimmung). Esta visa remeter - ser-aí (Dasein) ao espaço aberto que se efetiva como lugar de realização de sua existência. A tonalidade afetiva dimensiona a inserção do ser-aí ao mundo, marcando decisivamente sua relação com tudo aquilo que se apresenta no seio do aberto. Tais fenômenos são, mediante características específicas de abertura, compreendidas como tonalidades afetivas fundamentais (Grundstimmung), instâncias essenciais por situarem o ser-aí na tentativa de se singularizar no bojo do horizonte semântico que é o seu. Logo, tais afecções se notabilizam por igualmente abrirem o âmbito do desvelamento do seer (Seyn), apreendido em sua radical diferença ao ente, se notabilizando como articulações que possibilitam a manifestação do ser no ente. Esse acontecimento, por fim, urde a clareira para que acene a questão da verdade do seer.

Palavras-chave: Ser. Tonalidade Afetiva. Disposição. Espanto.

\section{Abstract}

This research seeks to clarify some outlines of a concept-experience central to Martin Heidegger's philosophy: the notion of affective tonality (Stimmung). This aims to send the being-there (Dasein) to the open space that becomes effective as a place of realization of its existence. The affective tone measures the insertion of the being-there into the world, decisively marking its relationship with everything that appears in the open bosom. Such phenomena are, by means of specific characteristics of openness, understood as fundamental affective tones (Grudstimmung), essential instances for situating the beingthere in an attempt to singularize itself within the semantic horizon that is yours. Therefore, such affections are notable for also opening up the scope of the unveiling of the seer (Seyn), apprehended in its radical difference to the being, being noted as 
articulations that enable the manifestation of the being in the being. This event, finally, urges the clearing to raise the question of the truth of the seer.

Keywords: Being. Affective Tone. Disposition. Wonder.

Para Izabela Bocayuva.

\section{Introdução}

O filosofar não se origina de uma mera conexão ou estudo da história da filosofia. Esta palavra, em muitos sentidos, resguarda uma riqueza semântica como poucas, e em muitas interpretações ao longo de sua tradição foram se oferecendo esclarecimentos situados dentro de determinadas tonalidades afetivas. Melhor: não há filosofia senão em uma tonalidade afetiva (Stimmung). Stimmung é um fenômeno que ganha todo o seu colorido na dinâmica que perfaz o existir humano. Não interessa para essa pesquisa analisá-la a partir de quaisquer balizadores psíquicos ou antropológicos, até porque não se percebe nesses horizontes quaisquer elementos que possam conferir à questão uma perspectiva de originariedade.

Segundo Martin Heidegger (1889-1976), são variados os acenos que as tonalidades afetivas oferecem à existência. Um deles diz respeito ao fato de serem determinantes para o descerramento das possibilidades de realização do ser-aí $(\text { Dasein })^{1}$ em suas práxis cotidianas. Não há outra forma de imersão no espaço existencial senão já tendo sido tomado, perpassado ou afinado pelas dimensões por elas inauguradas. São, assim, responsáveis pela afinação do ser do homem de maneira a deslocar a compreensão - fenômeno central na composição própria da abertura - para um plano subsequente de possível empenho nas relações que se desvelam, primeiramente, a partir das tonalidades afetivas. Elas conferem um tom e instauram um clima pregnante de toda e qualquer ação.

\footnotetext{
${ }^{1}$ O ser-aí (Dasein) é o ser do homem analisado e compreendido ontologicamente a partir de seus índices existenciais, sendo interpretado como e a partir de suas possibilidades de ser. Mundo, como aqui será entendido, não é orbe celeste ou planeta, sociedade, comunidade ou objeto. Explicita o espaço que circunscreve a esteira de realizações do ser-aí, não havendo quaisquer sobreposições entre duas coisas dadas, já que esses se copertencem, sendo um único e mesmo constructo: ser-no-mundo.
} 
Diferentemente do que possa parecer aos mais desavisados, "tom" e "clima", assim como aqui ocorrerá com a palavra "atmosfera", neste caso, não caracterizam algo que acidentalmente estaria associado às nossas ações. Por mais que possam se alterar, é invariável que toda ação aconteça já determinada por um "tom" e um "clima", sejam eles quais forem. Por isso, seu deslocamento empreendido no compreender (Verstehen) ${ }^{2}$ não significa algo fortuito ou qualquer dado menor quanto ao exame das possibilidades de realização da abertura (Erschlossenheit $^{3}$ como espaço que forja e efetiva o existir. A absorção no mencionado clima só ocorre quando se compreende não teoricamente o mesmo, o que faz da tonalidade afetiva um fenômeno ou afeto de situação, isto é, uma possibilidade de instauração de nexos que mostram ao ser-aí, apreendido a partir de sua urdidura existencial, como ele está e se torna quando imerso na realização de si na malha dos sentidos que se apresentam em seu cotidiano.

Tal experiência acena para algo de decisivo, a saber: que as tonalidades afetivas são a forma mais singular de abertura, e, por isso mesmo, um jeito determinante de ruptura com o tecido conceitual comum, quando se trata de uma tonalidade afetiva fundamental (Grundstimmung); "fundamental" justo por delimitar a singularidade de cada ser-aí específico: sua historicidade (Geschichtlichkeit) ${ }^{4}$. A Stimmung passa a configurar uma dinâmica possível de descerramento de horizontes hermenêuticos. Assim sendo, ela é instauradora da cotidianidade, e, igualmente, um elemento modal de quebra com essa mesma malha semântica. Com os dados lançados, fica evidente que não há possibilidades de filosofar sem estar afetiva ${ }^{5}$ ou afinadamente perpassado pela Stimmung. Dessa

2 Esta compreensão é examinada por Heidegger como um fenômeno central à abertura, significando a estrutura que dimensiona a inserção do ser-aí (Dasein) em seu ser possível.

3 A abertura deve ser entendida como um protofenômeno ontológico-existencial que faz erigir o constructo ser-no-mundo, visto que se distingue enquanto canal de realização indissolúvel de toda tarefa e empenho, perfazendo uma instância de distinção modal que rege e faz desse ente o lugar tenente de aparecimento e desvelamento do ser.

4 Heidegger tece uma profunda distinção acerca desse termo em relação à tradição. História (Geschichte) delimita as determinações epocais do ser e seus desdobramentos nos projetos históricos de mundo, constitui-se a partir da dinâmica mesma do tempo, isto é, da ekstase do passado que se efetiva no presente abrindo o porvir do futuro. Essa experiência é distinta de história (Historie) ou historiografia, o estudo científico acerca dos fatos ocorridos no passado.

${ }^{5} \mathrm{O}$ que se constata ao se colocar em questão noções como afeto ou sentimento, é que Heidegger, ainda que não as utilize explicitamente, abre a possibilidade de vertermos a interpretação de tonalidade afetiva por afeto. Parece-nos que a tonalidade afetiva é uma forma determinada de afecção, se esse termo for apreendido como algo que sintoniza, harmoniza ou afina uma forma específica de se interessar por, e não meramente como uma maneira de comoção, algo que se manifesta como uma patologia. O ponto central a ser esclarecido com este trabalho é precisamente 
maneira, filosofar é entrar em certo tom, em certo ritmo, em certa harmonia, fenômenos que estão para além de uma mera apreensão racional.

As tonalidades afetivas são jeitos nos quais se está disposto no interior da malha semântica sedimentada em que se é jogado, afinando o ente ${ }^{6}$ que tem em jogo seu próprio ser com o mundo que é o seu. Isto diz respeito uma vez mais ao significado próprio da palavra Stimmung. Esse termo vem de Stimme, "voz", "voto", vocábulo que também gerou stimmen, que significa "deixar ouvir a voz de alguém", "tornar harmônico, idêntico". Esse vocábulo se conecta com bestimmen, "determinar", "destinar" - o que, como se perceberá, já deixa entrever uma íntima relação com a História (Geschichte) ${ }^{7}$. Stimmung é uma palavra usada quando se precisa afinar um instrumento musical. O particípio passado gestimmt expressa algo de acordo, em um certo humor, palavra que deu origem a Gestimmtheit e Gestimmesein, concordância, ter e estar em um humor, estar em sintonia.

\section{Acontecimento apropriador, verdade e início}

É sabido que desde os gregos a filosofia nasce do espanto (thaûma). Nas palavras de Heidegger: “(...) que o ente permaneça recolhido no ser, que no fenômeno do ser se manifesta o ente; isto jogava os gregos, e a eles primeiro unicamente, no espanto. Ente no ser: isto se tornou para os gregos o mais espantoso" (HEIDEGGER, 1996, p. 32). Na linha desse texto, já se supõe certo perigo ao se escrever sobre qualquer tonalidade afetiva - sobretudo ao considerar o fato que o espanto é uma tonalidade afetiva fundamental para esta inquirição. Quando se reflete sobre algum afeto, há o risco de ele se esquivar e voltar, em seu velamento, que é a sua morada silenciosa.

As tonalidades afetivas fazem, assim, que o ente apresentado possa ser melhor otimizado na ocupação cotidiana, o que justifica a dificuldade de se pensar

a dinâmica de como tais afecções perpassam o ser do homem e o sintonizam àquilo que se abre, ou seja, o que se mostra em seu ser mesmo. Heidegger, já em Ser e Tempo, deixará às claras essa dimensão de análise.

${ }^{6}$ Deve-se compreender por ente tudo o que de algum modo é; os eventos, as coisas, o homem, a pedra, o céu, enfim, tudo o que de algum modo aparece e significa algo. "Ente é tudo o que falamos dessa ou daquela maneira, ente é também o que e como nós mesmos somos" (HEIDEGGER, 2008c, p. 42), como já escrito em Ser e Tempo.

7 No tópico intitulado "Destino, historicidade e retenção" do presente artigo se explicitarão melhor o significado e as possíveis relações entre História e tonalidade afetiva. 
algo que, ao procurar adentrar no problema, se esquiva e se esgueira em seu ocultamento. O espanto, como tonalidade afetiva fundamental do filosofar, é aquele que deixa e faz ver este recolhimento do seer $^{3}$, dobrado em sua diferença ontológica $^{9}$, o que concede às tonalidades afetivas sua experiência ontológica radical. Ou seja, o espaço de realização de uma tonalidade afetiva é o lugar no qual se desenrola a diferença ontológica. A filosofia acontece enquanto tal no interstício entre seer (delimitada pela diferença ontológica) e ente, e a tonalidade afetiva é o que afina e concede o tom desse interstício ontológico.

Ora, é necessário que o ser-aí seja tomado por isso que se manifesta. Ser tomado significa estar no aberto do seer. Em Hinos de Hölderlin, Heidegger apontará para a superação da expressão ser tomado por, que não mais terá voz em seu pensamento nas obras posteriores à mencionada preleção de 1934/35. A própria dinâmica do desvelamento, como aos poucos se vai aproximando, deverá ganhar outros contornos em relação àqueles anteriores à década de 1930, onde o divisor de águas será justamente a conferência Sobre a essência da verdade. A partir desse título, deve-se questionar a essência que o desvelamento, a verdade, possui. Esta seria uma "essência da essência" (HEIDEGGER, 2017, p. 62), a essencialidade que resguarda o seer em sua vigência determinante. Quanto à essencialidade própria da verdade, escreve Heidegger em As questões fundamentais da filosofia ("Problemas" seletos de "Lógica"), preleção do semestre de inverno de 1937/38:

A essência da verdade não é um mero conceito, uma ideia que os homens trazem na cabeça. Ao contrário, é a verdade que se essencia: ela é, em uma respectiva configuração essencial, o poder determinante para toda verdade e não-verdade, aquilo que é buscado, aquilo pelo que se luta e se sofre. A "essência" da

\footnotetext{
${ }^{8}$ O seer (Seyn), marcado pela dobra do e, situa-se em uma dimensão de absoluto deslocamento e ruptura com toda a metafísica precedente a Heidegger. $O$ autor, ao se valer desse recurso linguístico do antigo alemão, conecta o problema do seer à verdade e seu acontecimento históricotemporal, o que requisita o pensamento a se guiar por novas bases, ao ponto de impelir a filosofia do próprio Heidegger a um outro início.

9 Em linhas gerais, a diferença ontológica, como caracterizado na segunda parte da preleção de 1929 Os problemas fundamentais da fenomenologia, marca a diferença radical entre ser e ente, o que somente pode ser inquirido à luz da temporalidade originária e da transcendência, sendo essa caracterizada como a ultrapassagem do ente em direção ao seu ser, ou seja, seu sentido e verdade, não é outro fenômeno senão o acesso do ser-aí ao ente, por seu estar-lançado, por sua finitude/negatividade e inconsistência de seu ser, o que somente se faz possível pelo ser-aí encontrar-se em seu meio.
} 
verdade é um acontecimento, que é mais efetivo e mais real do que todas as ocorrências historiológicas, porque ela é seu fundamento (HEIDEGGER, 2017, p. 60).

O que deve ser delimitado pela essencialização é o seer como acontecimento apropriador (Ereignis). Este termo deve ser analisado em uma primeira instância como o evento da abertura proporcionada pelo ser em seu simultâneo ocultamento na diferença (ontológica) em relação ao ente. Percebe-se que o acontecimento apropriador, que deixa e faz aparecer o ente na totalidade como tal, se traduz pelo desvelamento, a alétheia: sua dinâmica de latência e ilatência, presença e ausência - que perfaz a dinâmica própria às tonalidades afetivas - que parte de um mesmo pressuposto, o de que 0 acontecimento apropriador resguarda a amplitude fenomênica de, concomitantemente, manifestar e ocultar o seer em sua radical diferença em relação ao ente.

Isso permite compreender a proximidade existente entre esses fenômenos - acontecimento apropriador e verdade - com as tonalidades afetivas marcando sua articulação (ou tom ${ }^{10}$ ) de aparecimento e ocultação, bem como a criação de uma atmosfera pela qual o ente se mostra em seu ser mesmo. Isso significa que a possibilidade de criação de projetos históricos de mundo só é factível quando as tonalidades afetivas espacializam e abrem os horizontes de desvelamento do ser. Tal possibilidade revela o seer para que venha acontecer no ente, de modo a permitir que a dinâmica histórica do existir do ser-aí torne-se possível.

Nesse momento já não se trata de um ser-aí lançado no mundo enquanto horizonte fático, mas da constituição própria dos projetos históricos de mundo que são urdidos pelas regiões abertas do seer. Tão-somente quando o ente faz parte da carne do mundo, quer dizer, quando desvelado, que vem a ser e, ao mesmo tempo, o ente só entra nessa condição quando disposto no âmago de um espaço descerrado já harmonizado com o todo desvelado. Sem o acontecimento apropriador não há mundo, e, por sua vez, não há ente.

O acontecimento apropriador mantém uma dupla tensão: constitui-se como condição de manifestação e desvelamento deixando que o ente venha a lume, e,

10 Deve-se perceber que na estrutura aqui descrita, a tonalidade afetiva, como a afinação e articulação própria entre o acontecimento apropriador e a verdade, que começa a ser esboçada, aparece como campo de jogo e realização que cria e gera o tom, um espaço aberto. Esse tom perfaz o clima, a atmosfera que harmoniza e acorda a eclosão do ente na totalidade pelo seer. 
simultaneamente, resguarda-se no ocultamento da diferença ontológica originada da relação entre ser e ente para que este último possa, efetivamente, vir a ser. Se todo ente ganha sua condição de possibilidade a partir do acontecimento apropriador - o que uma vez mais significa irromper como verdade (afirmação que será justificada adiante) -, seria talvez inútil procurar oferecer exemplos práticos para esclarecer isso.

Todavia, em se tratando de Heidegger, até mesmo o óbvio é problemático. Não existe $o$ acontecimento apropriador, porém um acontecimento apropriador determinado que se dá constantemente. Este, por seu turno, se desdobra sob uma tonalidade afetiva que pode de alguma forma afinar e abrir a possibilidade originária de tal realização. O próprio ato de filosofar não é diferente nesse aspecto. Filosofa-se perpassado por certa tonalidade afetiva fundamental, que por sua via alcança ou se põe na prontidão e atenção para auscultar o seer em sua diferença (ontológica). A realização do aí pelo acontecimento apropriador ocorre na tonalidade afetiva, em especial as fundamentais. Com isso, percebe-se que não é o ser-aí que ainda ocupa um lugar de destaque na economia conceitual do pensamento de Heidegger posterior à viragem (Kehre). Entretanto, é a articulação interna aos projetos históricos de mundo (que se dará pelo seu "aí") que ganha realce como história do seer. Com tudo isso, a questão relativa à essência da verdade é, definitivamente, a questão da verdade da essência.

Nessa viragem do pensamento, em que há um deslocamento da essência da verdade para a verdade da essência, situa-se a meditação filosófica mais determinante de Heidegger. A viragem se posiciona na dimensão que doa os contornos singulares da meditação filosófica radical. Depreende-se intimamente que essa filosofia já não se centra em uma analítica sobre o ente, ainda que privilegiado, como outrora fora o ser-aí. Entretanto, essa é uma articulação que põe em realce a instância que mais aguça o sentido mesmo de manifestação do seer em sua dobra e diferença.

O ser-aí será, nos textos de meados dos anos de 1930 em diante, pensado a partir de seu aí, o que, ainda que não mais ocupando um lugar de destaque, tal como ocorria, por exemplo, em Ser e Tempo, continua sendo uma noção basilar do pensamento posterior a esse momento. O lugar decisivo da ontologia passa a ser a rearticulação histórica do mundo, meditada a partir do acontecimento 
mesmo do aí - logo, não se tratando mais propriamente de uma analítica da existência. Para nosso autor, o que a filosofia precisa, de maneira mais radical e terminante, é pensar esse acontecimento. Essa experiência balizaria um outro início, distinto daquele empreendido pelos gregos; já não se trataria tão-somente de um segundo ou de uma forma qualquer de um novo princípio, mas efetivamente de um outro início.

Diversamente de começo, o início (Anfang) origina absolutamente tudo. Esta é uma instância que se coloca para além da história e que dimensiona todos os seus desdobramentos. O começo (Beginn), por sua vez, anuncia a partida de um movimento, o primeiro ponto de uma trajetória. Todo início é origem, diferente de começo. Em suma: “'Princípio' não é o mesmo que 'começo'” (HEIDEGGER, 2004, p. 11), tal como Heidegger indicou em Hinos de Hölderlin, sendo que nessa ocasião o termo "princípio" traduzia igualmente a palavra alemã Anfang. 0 começo não é senão algo do qual se parte, enquanto o início é muito próximo de princípio, no sentido grego do termo arkhé, aquilo do qual emana toda forma possível de ser, elemento originário do qual todas as coisas advêm. $\mathrm{Na}$ esteira da totalidade dos eventos, o começo é logo esquecido, enquanto o início ininterruptamente interpela o ser-aí.

Início, princípio, arkhé, como o próprio Heidegger associa esses termos em Que é isto - a Filosofia?, texto constante em Conferências e escritos filosóficos, caracteriza aquilo a partir do qual algo se manifesta, não desaparecendo quando o ente vem à tona, mas possibilitando originariamente seu aparecimento. É o seer, em absoluta e ressonante diferença, que impera e se cala no ente que diz, isto é, que se mostra. O seer fala em silêncio, revelando o ente como tal, sendo na totalidade, e ao passo que eclode em sua manifestação, já se resguarda no ocultamento. É o que está em latência quanto àquilo que se desvela e que, por sua vez, se abriga no velamento. Essa dinâmica de velamento-desvelamento é o que melhor traduz o próprio fenômeno da verdade.

O início, como Heidegger delimita em sua obra Sobre o início, preleção que data dos difíceis anos de 1941, é a expressão da própria verdade do seer. A essencialização do início ocorre no acontecimento apropriador, sendo esses fenômenos copertencentes. Não mais se pensa o ser através do ente; o início caracteriza a essencialização da própria essência, isto é, o seer e sua radical dobra 
e diferença, dobra aqui entendida como aquele ponto de desdobramento entre ente e ser, isto é, a própria diferença que permanece inquestionada; o seer que já não é absoluto e incondicional, porém, se realiza como acontecimento apropriador: o início é o acontecimento apropriador, como delimitado em Sobre o início.

O pensar que considera o início traz em sua semântica a possibilidade de apropriar, ser apropriado. O início, por seu turno, é sempre princípio, arkhé que resguarda a união e dimensão própria do velamento e desvelamento, sendo, consequentemente, o berço de toda verdade. A latência-ilatência é a mãe de toda verdade - o paradoxo entre presença e ausência é a articulação plena do seer, como já expresso em Os conceitos fundamentais da metafísica. Em suma, o início perpassa toda e qualquer expressão que sustenta a revelação do seer, inclusive por tonalidades afetivas fundamentais. Isso explicita a afirmação da passagem a seguir, extraída de Contribuições à Filosofia: do acontecimento apropriador.

Todo pensar essencial exige que seus pensamentos e suas proposições sejam a cada vez cunhados de maneira nova como bronze a partir da tonalidade afetiva fundamental. Se a tonalidade afetiva permanecer de fora, então tudo é um falatório imposto de conceitos e cápsulas vocabulares. [...] A questão é que a tonalidade afetiva fundamental afina o ser-aí e, com isto, o pensar como projeto de verdade do seer na palavra e no conceito (HEIDEGGER, 2015, p. 25).

O início não tem fundamento. Com isso, o filósofo busca destruir todo resquício de linguagem metafísica tradicional em seu pensamento. $O$ início não é um princípio a partir de um fundamento, visto que é o recolhimento e dação originária do seer em que desvelamento e velamento traduzem a ressonância própria dessa indigência. É a verdade, já em um modo mais acentuado que aquele exposto em Sobre a essência da verdade, uma forma decisiva de apropriar o seer. Entretanto, qual a relação entre a arkhé, isto é, início e seer, bem como o nexo estrutural desses fenômenos? Heidegger mesmo responde em Sobre o início, § 4, cujo título é Início e acontecimento apropriativo: "O início é essencialmente igual ao acontecimento apropriador, sua própria plenitude essencial em sua simplicidade" (HEIDEGGER, 2007, p. 30). A "simplicidade" que o pensador marca 
caracteriza o velamento e desvelamento próprios da verdade - alétheia -, sendo igualmente a essencialização do ser-aí, bem como a estrutura mais determinante de toda tonalidade afetiva. Isso ocorre pelo fato de as tonalidades afetivas estarem presentes, embora estejam de maneira decisivamente ocultas em ações e desvelamentos determinados ${ }^{11}$. Sem a essência da verdade não há início; sem essa essência, que configura o seer em sua originariedade, não há tonalidade afetiva, logo, não há início e nem filosofia, já que não haverá tonalidade afetiva que a possibilite. Pensar esse início, enquanto o outro início da filosofia, é sobretudo imergir no seio da diferença que delineia os contornos próprios do acontecimento e início do seer na verdade.

O plano de retomar as tonalidades afetivas e o ser-aí é, na perspectiva de Heidegger, a possibilidade mais determinante de ultrapassamento do primeiro início, não pelo fato de assim ajudar a superá-la, no sentido de abandoná-la definitivamente, mas voltando-se para as suas raízes que foram paulatinamente esquecidas $^{12}$ com o desenvolvimento de sua História. $O$ que há é um esforço obstinado de regressar à verdade original do seer, do acontecimento apropriador. "(...) Nós nos encontramos no âmbito daquele fim que é o fim do primeiro início" (HEIDEGGER, 2017, p. 161).

Em $O$ fim da filosofia e a tarefa do pensamento, conferência proferida em 1964, o fim do primeiro início aparece como algo decisivo, uma vez que é a possibilidade de efetivamente preparar determinado terreno para que outro início, que possa ultrapassar a metafísica, irrompa com a radicalidade necessária. 0 imperativo de superação da metafísica não significa, de modo nenhum, que ela tenha atingido sua consumação. Por outro lado, também não quer dizer que jamais tenha alcançado algum vigor. Cada filosofia teve seu lugar e importância, não sendo uma maior ou melhor que outra.

O fim da filosofia ou do primeiro início do filosofar nada tem a ver com o término de seu modo especial de pensar. Será no cerne desse fim que emergirá uma nova maneira de se posicionar frente aos problemas da própria filosofia, não

\footnotetext{
${ }^{11}$ É necessário que se tenha em vista que uma tonalidade afetiva não é "percebida" como tal; isto é, na medida em que acontece, ela já se resguarda da dimensão compreensiva. Se, por sua vez, a compreensão incide sobre ela, simultaneamente essa tonalidade afetiva já se esgueira à retração.

12 Consequentemente, é de se afirmar que, para Heidegger, Platão e Aristóteles perfazem a gênese do esquecimento do ser (Cf. Ser e Verdade, 2007).
} 
mais orientada pela metafísica 13 . "Fim", em outro contexto, indica a dimensão de destruição e esgotamento do Ocidente, algo para o que Heidegger já havia apontado há muito em Introdução à metafísica, de 1935:

\begin{abstract}
A destruição espiritual da Terra já foi tão longe, que os povos se veem ameaçados de perder a última força de espírito, capaz de os fazerem simplesmente ver e avaliar, como tal, a decadência (entendida com relação ao destino do ser). Essa simples constatação não tem nada a ver com pessimismo cultural nem tão pouco, como é óbvio, com um otimismo. Com efeito, o obscurecimento do mundo, a fuga dos deuses, a destruição da terra, a massificação do homem, a suspeita odiosa contra tudo que é criador e livre, já atingiu, em toda orbe, dimensões tais, que categorias tão pueris, como pessimismo e otimismo, de há muito se tornaram ridículas (HEIDEGGER, 1969, p. 65).
\end{abstract}

Este não é o momento para se discutir o niilismo heideggeriano. No entanto, o fragmento acima expõe de forma muito objetiva um aspecto de obnubilação do Ocidente $^{14}$, o seu fim. A filosofia, por seu turno, sem a pressurosidade típica da física ou da matemática, não busca oferecer respostas objetivas. Ela é pensamento meditante que se exercita na ação; não pode estar desvinculada da ação, em especial a ação do pensar. A filosofia não tem nenhum ar de ciência ou visão de mundo; com efeito, é definitivamente um interrogar acerca do ser dos entes. Outro início é preciso, visto que o próprio grego, ao não se interrogar sobre a alétheia - dentre outras tantas palavras originárias -, deixou aberta a questão sobre o fundamento desse termo, pois, com a direção tomada pela metafísica no período áureo do pensamento grego, a pergunta pela essência da alétheia se conformou à questão: o que é o ente? É do ente que a alétheia e sua essência se distinguem.

\footnotetext{
13 Uma questão que virá à tona nesse desdobramento do fim da filosofia como metafísica será, de um lado, o desencadeamento da técnica e da maquinação, e, de outro, a necessidade agora radical do pensamento meditante. Que pensamento é esse? Não outro que seja diferente daquele que já pensa sobre a alétheia: a vigência do seer em sua diferença ontológica que expressa sua latênciailatência, a clareira que deixa o ser aparecer e igualmente se ocultar; em suma, o acontecimento apropriador. É esta a "questão do pensamento" (HEIDEGGER, 1996, p. 95), e o lugar próprio ocupado pela tonalidade afetiva fundamental da retenção, que virá à lume adiante.

14 "Ocidente", como Heidegger repetidamente escreve - com "O" maiúsculo, como a exemplo, sobretudo, de Introdução à metafísica -, não se refere a um plano geográfico ou geopolítico. É antes o projeto originário de determinação dos modos de ser que são próprios do ser-aí atual - a História do seer. Logo, Ocidente é o âmbito Histórico de atuação do ser-aí epocalmente, de maneira a traduzir suas possibilidades mais imediatas de ser e agir.
} 
O primeiro início já estabelece o seu respectivo fim, haja vista que nele se radica o esquecimento do ser. $O$ segundo ou outro início questiona, de modo distinto, o seer em sua diferença em relação ao ente, sem nenhuma interferência de adequação, em sentido moderno, perguntando por sua dimensão de manifestação e ocultamento a partir da imposição de algo radical, por isso indigente: a diferença que reside na dobra do seer. Nesse sentido, seer, início e acontecimento apropriador dizem o mesmo. Em As questões fundamentais da filosofia, o quinto capítulo da parte principal aponta para a direção para a qual se deve olhar a fim de ver um fenômeno que passou despercebido. O referido capítulo traz por título: $A$ indigência e a necessidade do primeiro início e a indigência e a necessidade de um outro questionamento e iniciar. Esse termo essencial acena para o outro início, para uma maneira diversa de se examinar o seer.

\section{Arkhé, páthos e thaûma}

Em relação às análises tardias do ser-aí, a indigência não se trata de uma penúria e nem de uma miséria. Por fundar-se em seus meandros, no seer não há fora e nem dentro, pois a indigência abre um determinado espaço em que ainda não se deu nenhum essenciar. Entretanto, resguarda em si o mesmo em latência. A indigência é uma tonalidade afetiva que se refere ao reconhecimento de sua finitude. Tal fenômeno é um modo determinado do seer.

O "aí" (Da), de ser-aí, expressa o "ek-" de eksistere. Isso significa que no cerne do existir, este ente deve se manter na exterioridade, como que remetido para fora de si. Este $D a$ é, em alemão, o advérbio de lugar "aí", que entendido ontologicamente se refere à dimensão espacial própria desse ente, já que este deve estar "lá", "aqui" e "acolá", visto que o aí indica uma localização, um espaço de apropriação de si. Essa localização, que não é espacial no sentido de métrica ou relativamente à área de um intervalo entre certos limites, uma extensão de, posiciona antecipadamente mais uma vez esse ente no seio da finitude que lhe é característica: lança-se, como expressa seu aí ininterruptamente aberto. 
A problemática de o ser-aí envolve um exercício de compreensão da finitude que o constitui, sendo essa o elemento mais imediato e irredutível que perfaz sua estrutura primeva, o fato de perfazer um ente que prescinde de fundamento ${ }^{15}$; melhor, a finitude, sendo o esteio no qual o ser desse ente é sustentado, é a condição que o libera para efetivar suas ações. Isso porque está rotineiramente encravado na dinâmica de se ganhar e perder ${ }^{16}$, uma vez que sua existência tem seu apoio repousado na negatividade que lhe é tão característica.

Sua indigência característica não expressa nenhuma privação, carência, no sentido de que algo falta, porém, faz transparecer a singularidade que marca o ser desse ente. Em Os conceitos fundamentais da metafísica (mundo-finitude-solidão), Heidegger delimitará que a essência do ser-aí é notadamente indigente. Todavia, isso não implica que ela seja miserável, falha, pobre. Anterior a essas concepções, é um elemento determinante que urde o fio da finitude no seio desse ente, sendo um caráter que lhe é positivo. Em outro momento de sua reflexão, em Questões fundamentais da filosofia: ("Problemas" seletos de "Lógica"), preleção do semestre de inverno de 1937/38, a indigência já estará atrelada à tonalidade afetiva fundamental do espanto, sendo um elemento determinante para o próprio início da filosofia. Para ser mais preciso: como se escreveu acima, este é um ente que prescinde de fundamento. Não há apoio, não há base, não há nada que sustente seu ser; ou, sendo mais claro, apenas tem esse Nada ${ }^{17}$ por "fundamento".

\footnotetext{
${ }^{15}$ Heidegger, em $O$ fim da filosofia e a tarefa do pensamento, que data de 1964, assim define fundamento: "Fundamento é aquilo de onde o ente como tal, em seu tornar-se, passar e permanecer, é aquilo que é e como é, enquanto cognoscível, manipulável e transformável" (HEIDEGGER, 1996, p. 95).

16 Esta dinâmica de perda e conquista de si mesmo constitui o movimento cotidiano que é acentuado pelos contornos da decadência. A decadência é delimitada como a estrutura mais nuclear da impessoalidade mediana, guiada pelo falatório, curiosidade e ambiguidade que se efetivam como modos básicos de ser através de uma condição de aprisionamento, alienação e tentação que tranquilizam o ser-aí no bojo da cotidianidade.

${ }^{17}$ Em linhas gerais, Nada não se deixa ver como qualquer entidade específica, mas como condição de possibilidade dos entes serem, caracterizando a predominância e "inquietude do não", como exposto em $O$ que é metafísica? e em Os conceitos fundamentais da metafísica (mundo - finitude solidão), isto é, da negatividade, como nomeado por Heidegger nessa última obra. Fizemos a escolha metodológica em não dizer o nada, uma vez que o artigo abriria margem para entender 0 nada como ente. Isso ocorrerá quando for essa a situação. Por isso mesmo, essa referência neste artigo sobre o fenômeno do Nada será feita com "N" maiúsculo - mas com o artigo, embora seja radicalmente necessário não o confundir com um pronome indefinido ou mesmo com um substantivo. É claro que, ainda assim, não se consegue, em absoluto, apartar a dinâmica entitativa - ôntica - em relação ao Nada, como neste caso. A linguagem praticamente não permite fazer uma referência a algo senão por uma preposição ou conjunção - a própria referência " a algo" já explicita essa restrição. O limite do fenômeno está na linguagem, que autonomamente entifica-o. Por mais que tentemos não o apreender como ôntico, as palavras nos traem. E o próprio
} 
É nessa dimensão que o ser-aí, imerso no interior dessa relação, se vê pela primeira vez em meio à totalidade do ente. Ela radicalmente diferencia o seer em relação ao ente, até porque este meramente ainda não aconteceu como tal, pois ganhará seu vigor na própria latência do seer, é ela que separa decisivamente o seer e o ente, determinando - como dado fundamental mesmo da alétheia - o ente ainda não desnudado. A indigência está na base da correspondência entre seer e ente, que, por sua vez, é o elemento estrutural da diferença ontológica, no qual o ser-aí se insere e habita. A referida demora na resposta é a constatação apolínea da diferença ontológica, uma vez que é nessa correspondência que reside a mencionada diferença. Afirmava Heidegger em Que é isto - a Filosofia?

Não estamos nós homens já sempre numa tal correspondência, e não apenas de fato, mas do mais íntimo de nosso ser? Não constitui esta correspondência o traço fundamental de nosso ser?

$\mathrm{Na}$ verdade, esta é a situação. Mas, se a situação é esta, então não podemos dizer que primeiro nos devemos situar nesta correspondência. E, contudo, dizemos isto com razão. Pois nós residimos, sem dúvida, sempre e em toda parte, na correspondência do ser do ente; entretanto, só raramente somos atentos à inspiração do ser. Não há dúvida que à correspondência ao ser do ente permanece nossa morada constante (HEIDEGGER, 1996, p. 36 - itálico nosso).

Nesse mesmo escrito, Heidegger define o que se entende por Filosofia: "O corresponder ao ser do ente é a filosofia". O ser-aí habita essa correspondência entre ser e ente, e as tonalidades afetivas nos transpõem, mediante os apelos do próprio seer em sua diferença, para o bojo dessa situação inaudita. Por conseguinte, está na base das tonalidades afetivas o "modo como fala o apelo do

\footnotetext{
Heidegger sabia disso, pois escreve repetidamente "o nada", nos textos supracitados, como um ente, ainda que especial. Assim, pretende-se marcar o fenômeno do ponto de vista ontológico, e não ôntico. No presente contexto, o Nada é evidenciado pela tonalidade afetiva fundamental da angústia, que não é senão a assunção da estranheza de ser livre. Tal questão precisa ser esclarecida a partir da semântica própria da verdade (alétheia), o desvelamento, o que faremos conectando essa problemática à inquirição das tonalidades afetivas fundamentais, em especial, a retenção. A angústia manifesta o extraordinário de o ser-aí se apreender, ainda que não em termos cognitivos, mas existenciais, como ente, arrancando-o de sua familiaridade cotidiana de modo a acenar para a sua singularização na morte. O ser-aí é o seu poder-ser, e ganha a sua autenticidade quando toma sobre si seu ser-para-a-morte. O Nada, como escrito por Heidegger em Sobre o início, preleção que data de 1941, é testemunha da diferença do ser (seer) com o ente, sendo intrínseco à experiência do início.
} 
ser", a abertura da clareira ${ }^{18}$, visto que é por meio desta que a correspondência entre ser e ente acontece de modo a vir a lume o mundo. A ausculta é a estrutura que torna acessível a correspondência com relação àquilo que se manifesta. Por isso mesmo, pouco se liga a aparelho auditivo e barulho. É antes um deixar-se conduzir pelo canto silente daquilo que o acontecimento apropriador já ressoou. Assim sendo, este corresponder já é, de antemão, um afinar. A base da correspondência da diferença ontológica é a afinação ocasionada pela tonalidade afetiva; ela harmoniza a própria diferença ontológica.

$\mathrm{Na}$ esteira dessa discussão, nosso filósofo procurou enfatizar que as tonalidades afetivas passarão a ser delimitadas como elementos modais que caracterizam a diferença ontológica. As questões fundamentais da filosofia é uma obra basilar para delimitar esse âmbito de total radicalização quanto às afinações, visto que essas não mais estão em algum horizonte determinado. $A$ indigência expressa precisamente esse elemento de decisiva radicalidade: é a caracterização do mais radical não - que passa a responder ao ente, o qual se diferenciou por ser, apenas, ente. Por isso a repetida conclusão de que as tonalidades afetivas expressam o mecanismo próprio do acontecimento apropriador. Elas estão na base do início, que é originado pelo seer, que, por conseguinte, será seu elemento delimitador não mais como termo estrutural do nexo ser-aí e mundo, porém, como espaço próprio de determinação do acontecimento apropriador, isto é, da dinâmica de aparecimento e ocultação próprios da alétheia. A tonalidade afetiva passa a configurar o horizonte do desenrolar da diferença ontológica. Isso nos possibilita afirmar que tonalidade afetiva e clareira, nesse ínterim, dizem o mesmo. $A$ indigência determina o ser-aí. O próprio Heidegger escreveu no $\S 36$ de $A s$ questões fundamentais da filosofia: "A tonalidade afetiva corretamente compreendida, porém, leva muito mais a uma superação da concepção até aqui de homem" (HEIDEGGER, 2017, p. 197).

A tonalidade afetiva deve ser apreendida, para além de uma dimensão da abertura do ente, como um elemento transportador que conduz o ser-aí para a indigência. Esta é, igualmente, uma indigência afinadora, que de forma inicial transpõe o ser-aí para o "entre", característico do início, que determina a essência

18 A clareira é a modulação da abertura que deixa o seer enquanto tal desvelar-se em seu acontecimento histórico-temporal, de maneira a fazer com que o ente, em sua diferença em relação ao próprio seer, possa aparecer. 
mesma do ente. Por isso mesmo, os afetos não forjam mundo; articulam a correspondência e transposição do ser-aí para o espaço aberto. O lugar desse entre é aquele que implica no limiar do ser que encarna no ente, possibilitando que este possa vir a se manifestar. Esta indigência, que expressa a gravidade do seer em sua completa dobra e diferença, exige uma determinada tonalidade afetiva fundamental a fim de que possa, por meio dela, instaurar um pensar inicial, um pensar meditante. No primeiro início, o ser fora identificado como arkhé, e esta foi nomeada, já nos pensamentos decisivos de Platão e Aristóteles, através da palavra espanto (thaûma).

O espantar-se (thaumázein) constitui fundamentalmente a arkhé, o princípio da filosofia em sua aurora grega. O princípio, que foi chamado outrora de início, está na base de tudo aquilo que vem a lume. A arkhé é expressa no verbo arkheĩn, isto é, o que impera, que delimita e doa o tom de algo. Por isso, Heidegger traduz em Que é isto - a Filosofia? o termo grego páthos por tonalidade afetiva. Há uma íntima relação entre arkhé e páthos. o início ou princípio fundamental do filosofar é guiado por uma tonalidade afetiva. Sem o início/princípio para meditar a radicalidade dos fatos, não há tonalidade afetiva. Logo, início e tonalidade afetiva são termos copertencentes e co-originários, cuja articulação interna não prescinde da mais íntima comunhão entre ambos.

Essa relação determinante entre arkhé e páthos, início/princípio e tonalidade afetiva, joga com o espaço mesmo do qual emerge a correspondência originária entre ser e ente que o ser-aí habitará. $O$ espanto, nesse sentido, não é apenas um estímulo para que possa se dar o filosofar. Mais uma vez nos valemos das indicações preciosas de Que é isto - a Filosofia?

O espanto é, enquanto páthos, a arkhé da filosofia. Devemos compreender, em seu pleno sentido, a palavra grega arkhé. Designa aquilo de onde algo surge. Mas este "de onde" não é deixado para trás no surgir; antes, a arkhé torna-se aquilo que é expresso pelo verbo arkhein, o que impera. $O$ páthos não está apenas no começo da filosofia, como, por exemplo, o lavar das mãos precede a operação do cirurgião. $O$ espanto carrega a filosofia e impera em seu interior. (...) o espanto é arkhé - ele perpassa qualquer passo da filosofia. O espanto é páthos. Traduzimos habitualmente páthos por paixão, turbilhão afetivo. Mas páthos remonta a páskhein, sofrer, aguentar, suportar, 
tolerar, deixar-se levar por, deixar-se convocar por. É ousado, como sempre em tais casos, traduzir páthos por disposição afetiva [Stimmung], termo com que procuramos expressar uma tonalidade de humor que nos harmoniza e nos convoca por um apelo. Devemos, todavia, ousar essa tradução porque só ela nos impede de representar páthos psicologicamente no sentido da modernidade. Somente se compreendermos páthos como disposição afetiva podemos caracterizar melhor o thaumázein, o espanto. No espanto detemo-nos (HEIDEGGER, 1996, pp. 37-38).

Conforme nosso pensador, o filósofo deve habitar no espanto. Isso porque nele há um recuo diante do fato de as coisas ganharem sua dimensão e ser. Por esta tonalidade afetiva fundamental, testemunha-se o horizonte do recuo, quer dizer, de ocultamento do ser em sua verdade no seio do ente, possibilitando que este possa, de alguma maneira, sair de seu velamento. O espanto não é, por conseguinte, uma mera impressão ocasionada por algo de repentino e inesperado. Não se trata de um susto, um pasmo, ou mesmo de um vazio maravilhamento que se dá em relação a algo que acontece. O espanto é a tonalidade afetiva fundamental que apreende o aparecimento ou acontecimento da verdade, haja vista que nesse fenômeno radica-se a tarefa que caracteriza certa postura: o filosofar.

No espanto, tudo o que é mais habitual se torna o mais inabitual, aparentemente uniformizando as diferenças daquilo que se mostra. No espanto, tudo aquilo que possibilita alguma fuga desaparece no "extremo da inabitualidade" (HEIDEGGER, 2017, p. 213), de maneira que possa trazer à tona o ente como ente. Eis a sua tarefa e função. O que é habitual não é o ente como tal, nem mesmo o horizonte de entes que se desvelam em seu todo. Ele se abre em todas as circunstâncias e em todas as coisas, sendo por isso mesmo desconsiderado. O espanto será aquela afecção que corrói essa forma de abertura habitual, mostrando que o problema da abertura não se situa no ente, mas em sua essencialização, em seu acontecimento apropriador.

$\mathrm{Na}$ cotidianidade, todo o inabitual, mediante a sedimentação da cotidianidade do ser-aí, mostra-se como habitual, isto é, destituído em sua diferença e essência. "O espanto não permite nem a saída e nem a entrada, mas transpõe para diante e para o interior da inabitualidade de tudo em sua inabitualidade" (HEIDEGGER, 2017, p. 221). Este fenômeno permite a 
transposição oriunda da tonalidade afetiva fundamental para a inabitualidade. 0 que é habitual só se pode apresentar como tal na sua diferença, em seu oposto.

O ser-aí é arrastado ou transposto para o seio do acontecimento que possibilita o ente se mostrar como tal, por meio de sua inabitualidade. É decidido que este ente é inserido nesse fenômeno, e a ele suporta. O que se suporta é o reconhecimento do ente enquanto tal, possível somente na tonalidade afetiva fundamental do espanto, melhor, no questionamento ${ }^{19}$ do ente - no espanto de estar imerso nesse questionamento. Não há saída para o espanto, já que espantado o ser-aí perde seus recursos e mobilizadores de adentrar na lida com os entes dispostos. Eles se apresentam como tal em sua assoladora distinção e singularidade. Ademais, esse fenômeno em si mesmo não pode imergir no seio desse inabitual, o que faz dessa tonalidade afetiva residir no entre do inabitual e do habitual; não se sabe dentro e nem fora do habitual, traduzindo o caráter de absoluta indigência em que o seer mesmo se deixa despontar no âmago de seu acontecimento.

A tonalidade afetiva fundamental do espanto deve instalar-se no entre, pois precisa mantê-lo aberto e simultaneamente desperto, como que atento ${ }^{20}$ a essa condição. O espanto é uma recusa de toda e qualquer alternativa de fuga dessa experiência, sendo uma transposição para o em meio de. Essa tonalidade afetiva fundamental, por não se saber fora e nem dentro do ser-aí, perfaz algo que se estende à totalidade, revelando o ente como ente. $O$ espanto, deste modo, transpõe o ser-aí para a apreensão, do ente enquanto ente, sustentando-o em seu desvelamento, na instância em que acontece sua manifestação. O ser-aí afinado é transposto para a essência mesma do espanto, a saber, a sustentação do desvelamento que transpõe para a apreensão do ente como ente. O espanto é a tonalidade afetiva fundamental que diretamente se liga ao problema da verdade, pois o que espanta é o desvelamento do seer em sua diferença em relação ao ente. Em As questões fundamentais da filosofia escreveu o pensador:

\footnotetext{
19 Deve-se atentar com este questionamento, pois será ele que balizará a transposição do primeiro para o outro início do pensar, para uma "filosofia futura". Esse questionamento será determinado pela tonalidade afetiva fundamental da retenção.

20 Deve-se indicar que a atenção é um dos caracteres balizadores de toda tonalidade afetiva fundamental.
} 
Afinado no es-pantar, ele [o ser-aí] não consegue outra coisa senão apreender o ente enquanto ente, ou seja: o homem precisa tomar pé como es-pantado no recolhimento disso que irrompeu, precisa vê-lo em seu des-encobrimento insondável, experimentando e suportando a alétheia, o desvelamento, como a essência inicial do ente. Pois é isso, antes de tudo que precisamos aprender a conhecer: o fato de que a alétheia, o desvelamento, é, para o pensar inicial grego, a essência do próprio ser (HEIDEGGER, 2017, p. 215).

Se é assim efetivamente, o espanto é o mais determinante por ser inaugurador da verdade do seer, verdade num sentido mais originário, como que uma verdade ontológica. Com isso se constata diretamente a relação intrínseca entre tonalidade afetiva e verdade. Isso deixa igualmente revelar a essência mais decisiva de toda a tonalidade afetiva fundamental. O espanto é a tonalidade afetiva fundamental porque abre a dinâmica historial do seer, em outras palavras, aponta para o acontecimento de certo terror diante do que há de mais familiar e inoportuno, não um terror de pânico ou de um horror aversivo, mas o terror como o acossar do ente em sua diferença.

O espanto é inaugural quanto à instalação da diferença ontológica. Familiar, porque é uma fissura no habitual; inoportuno porque é a articulação e dação mesma de uma afinação que instaura uma ressonância na história do seer, em que essa ressonância se mostra como o próprio é do ente. Por ser a mais inabitual de todas as tonalidades afetivas, o espanto é a mais rara. "O es-panto é a tonalidade afetiva fundamental, que afina a princípio o homem no início do pensar, porque transpõe pela primeira vez o homem para $\circ$ interior daquela essência que se encontra e se dispõe em meio ao ente enquanto tal na totalidade" (HEIDEGGER, 2017, p. 217).

No espanto, aquele que assim está deve aprender a "suportar, tolerar, deixar-se levar por, deixar-se convocar por" (HEIDEGGER, 1996, pp. 37-38). Aquele que se deixa convocar é justamente o que escuta a voz de um apelo. A estranheza, não obstante, se constitui em um modo privilegiado de estar em uma escuta/ausculta. Se este é um processo de singularização, é salutar sustentar que uma tonalidade afetiva fundamental evoca outra. E por isso que a ausculta requer obediência e prontidão, que, por sua vez, devem ser suportadas (como escrito na passagem acima), e que o ser-aí deve, transposto, se deixar levar. 
De tal forma, é no espanto que o ser do ente se abre. Em seu bojo ocorre a mais crucial indigência que coloca em relevo a existência mesma do ser-aí e sua negatividade mais própria. O espanto é, de maneira decisiva, o palpitar da finitude, seu Éros, sua mais estrangeira morada; e mais, é também a afecção mais característica, pela qual o ser-aí pode vir a se singularizar. Isso leva Heidegger a abrir sua preleção As questões fundamentais da filosofia ("Problemas" seletos de "Lógica") com as seguintes palavras: "(...) pois justamente se e porque a filosofia é e continua sendo o pensamento mais tenaz oriundo da mais pura sobriedade, ela emerge e permanece em uma tonalidade afetiva maximamente elevada" (HEIDEGGER, 2017, p. 4). E toda essa estrutura não tem nem hora e nem lugar se não for entendida a partir de um horizonte histórico.

\section{Destino, historicidade e redenção}

Nessa pesquisa, não interessa o estudo da história como ciência que se detém ao exame de fatos passados. Quando se pensa em histórico o que se tem em vista, de maneira geral, é um termo polissêmico. A história não pode possuir somente um sentido de realidade histórica que se vale de uma dimensão temporal linear, bem como não há sentido em se meditar a história a partir de uma referência ao passado, como um ser simplesmente dado, um passado estático que possui (ou não) um efeito no presente, ou ainda enquanto um conjunto de circunstâncias e acontecimentos factuais que influenciam, de alguma maneira, o presente e o futuro. Não vem ao caso nessa análise entender o histórico como aquilo que é deixado à tradição, que pode se dar no tempo, como oposição à natureza, como o que ocorre em um sentido de destino, entendido enquanto um fato previamente determinado em sua totalidade. Isso sempre tem em vista "o homem como 'sujeito' dos acontecimentos" (HEIDEGGER, 2008c, p. 471), que controla o tempo e os eventos e que a partir de sua intencionalidade confere 0 transcurso da história.

O que todos esses significados da história revelam é o ser-aí como um ser simplesmente dado que entra na história - que é igualmente algo dado. O que Heidegger observa é que esses sentidos da história não estão equivocados - 
sendo por isso que resguarda o vocábulo Historie para representar esse entendimento -, mas não são oriundos do homem. O que se procura com a História, contudo, Geschichte, é a dimensão do transcurso do existir que se funda ontologicamente no tempo, conferindo a essa expressão um sentido de traduzir a história do ser no seio da existencialidade do ser-aí: "somente porque a presença [Dasein, ser-aí] é, em seu ser, histórica é que circunstâncias, dados e envios se tornam ontologicamente possíveis?" (HEIDEGGER, 2008c, p. 471), pergunta o filósofo no $\S 73$ de Ser e Tempo. Sendo, por sua vez, singularmente, o ser-aí se harmoniza às possibilidades que se apresentam à tradição ou herança que acometem o mundo sedimentado que é o seu. Isso abre a historicidade, e esta desenrola-se como destino, que deve ser entendido como o acontecer originário estruturado na decisão que abre uma possibilidade para si que é tanto herdada, como escolhida. O destino acontece como historicidade.

A historicidade deve ser tomada como destino que se configura no espaço existencial próprio a cada ser-aí de maneira a delimitar seus jeitos e envios, isto é, aberturas, afetos, afinações. Consequentemente, a historicidade é construída em cada desenrolar de experiências, projetos, situações - tal como explicitado acima. A historicidade deve perfazer um habitar, visto que a História como transfiguração do tempo no vigor de ter sido, que delimita os meandros e jeitos singulares de decidir-se no porvir, abre modos de conformações muito específicos de entrar ou abrir-se para atmosferas singulares. Isso explica por que a historicidade ganha sua medida própria ao passo que traduz um habitar.

Esse habitar tinha a mesma raiz etimológica de construir, buan. O que se constrói para ser habitado é algo edificado, não por alvenaria, argamassa ou vergalhão, mas com aberturas que urdem a cada vez um mundo como espaço ontológico e afetivo no qual se desenrola um existir. $O$ que isso procurava indicar é que não há pensar, como o filosófico, por exemplo, sem o afinar de um destino historial, sem os desdobramentos do ser no tempo, que traduz as ekstases determinantes que transfiguram e delineiam um corpo ou corporeidade, uma espacialidade, uma conformação, uma ipseidade. Conforma-se a, quer dizer, interessa-se pelo que o destino já sedimentou como historicidade por meio de tonalidades afetivas. Assim, corrobora-se com um posicionamento a ser defendido 
nesta investigação: primeiramente se sente o mundo, e não, ex-ante, se o compreende, como numa compreensão teorética, de categorias subjetivadas.

A historicidade é o transcurso mesmo do existir fático do ser-aí que se projeta no acontecimento do porvir que instaura a atualidade pelo vigor de ter sido - estrutura ekstática da temporalidade originária. Ela só pode ser efetivada através de experiências de envios e conformações singulares, decididas, resolutas, isto é, afinações e harmonizações autênticas. A História, enquanto tradução do desvelamento epocal do seer, determina originariamente as tonalidades afetivas. A tonalidade afetiva fundamental da retenção será aquela que melhor esclarecerá esse fenômeno. Só se habita segundo a tônica da historicidade sobretudo porque essa só acontece afinadoramente. Logo, só há habitar-se se está afinado singular e historicamente.

Não obstante, a questão filosófica mais elevada, segundo Heidegger, não poderia ser outra que a verdade do seer, revelada em sua diferença ontológica, já em absoluto apartada do ente. O questionamento se orienta singelamente por tonalidades afetivas muito elevadas. Isso porque devem romper com toda e qualquer dinâmica de estruturação do mundo fático; já se está muito além dessa perspectiva. Qual é a questão fundamental da filosofia, senão a tarefa de seu acontecimento, melhor, de se colocar na marcha do acontecimento mais decisivo, mais reluzente, deveras criador?

A verdade. essa é uma das questões almejadas nesta inquirição. Enviesarse para ela é procurar se posicionar nos meandros de seus contornos. É em sua cercania que se habita e sintoniza. Essa não é uma questão de ajustar uma tonalidade afetiva certa para se colocar no interior de seu acontecimento. É muito mais deslocar uma tonalidade afetiva para uma originária ou inicial reverberação. À procura pela verdade, uma tonalidade afetiva fundamental deve ganhar ressonância, e nesta precisa haver aquilo que o primeiro início da filosofia reservou como experiência chave para a realização de todo o filosofar, a saber, o espanto. O espanto é examinado quando se interrogar sobre a questão fundamental da filosofia. Ora, o espanto promove certo terror, já que é uma abertura privilegiada para o mais próximo, como igualmente aquilo que é mais inoportuno. Não obstante, o que se traduz como o que é mais assolador e 
decisivo? O mais espantoso, provou-se, é o acontecimento do ente, o fato de ele ser-e não nada.

Igualmente se desponta nessa análise que a verdade é a tradução do desvelamento que ocorre de forma originária no espanto. Entretanto, o terror frente à realização do ente se dá no mesmo instante junto a outro fator determinante, qual seja, o pudor de testemunhar a essencialização do seer, isto mesmo que faz o ente aparecer; mais detidamente: a tonalidade afetiva fundamental do pudor traduz tão-só o acontecimento apropriador, uma vez que este fenômeno mantém o espanto do terror. Há uma tonalidade afetiva fundamental que une o terror e o pudor, sendo essa a retenção. Conforme Heidegger, "(...) a retenção é aquela tonalidade afetiva na qual esse terror não é superado e alijado, mas, precisamente, resguardado e conservado por meio do pudor. A retenção é a tonalidade afetiva fundamental da ligação ao seer" (HEIDEGGER, 2017, p. 5). É a retenção a "arkhê" do outro início do filosofar.

A tonalidade afetiva fundamental da retenção se mostra em especial como meditação, já que revela a capacidade de o ser-aí filosofar. A tonalidade afetiva manifesta o jeito no qual o ser-aí está situado no seio desse desvelamento, de maneira que só há desvelamento se situando um ser-aí no âmago dessa manifestação. O que é revelado pela verdade, o seer, só é no ente; contudo, não pelo ente, e sim pelo desdobrar da clareira que deixa um horizonte de sentido acenar para um ser-aí atento e disposto em uma prontidão para tal acenar. Em linhas gerais: só há acenar para um ser-aí atento e pronto, de modo que esta atenção e prontidão para, que continuamente possibilitam a apreensão do pudor da retenção, possam vir também a despertar o ser-aí para o terror dessa mesma tonalidade afetiva fundamental.

A retenção é a tonalidade afetiva de ligação ao seer - a verdade ontológica, que agora recebe o nome de encobrir-se hesitante. o resguardo do seer em sua indigência e reclusão. Isso significa que nessa tonalidade afetiva há um salto prévio para a própria essencialização do seer, e essa questão é o esteio mesmo do ser-aí - já que assim foi escrito em As questões fundamentais da filosofia: "Pois a verdade como clareira para o encobrir-se é o fundamento para o ser do homem" (HEIDEGGER, 2017, p. 268). A retenção (Verhaltenheit) é uma postura de se deter diante do filosofar que procura o ente e, através de uma 
meditação cuidadosa, recusa todo pensar que se conduz à instrumentalização do mundo.

Destarte, em todo acontecimento da verdade, no qual se dá o evento seraí, é necessário que um desdobramento dessa condição prévia ocorra: o despertar de uma tonalidade afetiva fundamental, nesse momento, do outro início do filosofar. O que identifica o primeiro e o outro início do filosofar são tonalidades afetivas fundamentais. $\mathrm{O}$ primeiro início tinha no espanto a sua tonalidade afetiva disparadora, e o outro início tem no pavor do abandono do seer a retenção, sua tonalidade afetiva fundamental. Ambas acenam diretamente para a verdade: a primeira tonalidade afetiva indica a determinação central do filosofar enquanto o maravilhar frente ao desvelamento do ser; o outro início, que nada tem de algo que supera e/ou alija o primeiro, tem no pavor uma abertura para a verdade da indigência que outrora se explicitou, uma indigência da falta de indigência, a indigência de tudo que se perde no cálculo, no matemático. A retenção abre até mesmo para esta frente de ocupação do ser-aí. Nessa ótica afirma Heidegger:

Já designamos indigência com um nome: o abandono do ser. Explicitamos essa denominação e dissemos: o homem histórico empreende, usa e transforma o ente, experimentando a si mesmo como um ente - e o seer do ente não o interessa, como se ele fosse o que há de mais indiferente (HEIDEGGER, 2017, p. 261).

Perceba-se que essa indigência que traduz o abandono do ser é a mesma que funda o ser do ser-aí que, afetivamente, está aberto para a clareira do encobrir-se hesitante, isto é, para a verdade do seer. "A verdade, contudo, é a verdade do seer" (HEIDEGGER, 2017, p. 254), e todo desvelamento acontece no seio do aberto, que sintoniza e determina um ser-aí. Como se percebe na citação acima, não é mais a finitude do ser-aí que funda a tonalidade afetiva: com efeito, sua base está, quanto ao outro início, no próprio abandono do ser, vale dizer, na indigência desse abandono.

Para o desvelamento da verdade acontecer, o ser-aí já se afinou ao ser. A essenciação da verdade somente é alcançada, assim, por dois mecanismos: que essa essência só é revelada pela abertura histórica do ente e por meio do salto em que nós mesmos nos colocamos, a partir de uma tonalidade afetiva 
fundamental, como a retenção, a pensar o ente. O salto é experienciado quando, pela retenção, participamos criticamente do abandono do ser na indigência do seer. E isso poderia voltar a se dar no terror do espanto.

No terror do espanto, o ser-aí não fica "aterrorizado"; pelo contrário, há um maravilhamento frente ao que se deixa ver como tal, ainda que momentaneamente suspenda esse ente de sua mundanidade, edificando uma instância inaugural de realidade. A retenção se articula por meio de outras duas tonalidades afetivas, a saber, o terror e o pudor, como já expresso. O terror é a tradução do espantoso, que é o testemunho da indigência do seer, ou seja, é o dizer de toda a diferença ontológica, toda a experiência de recuo do ser. $\mathrm{O}$ espanto, se assim é entendido, refere-se já à verdade, uma vez que diz respeito ao recuo do seer deixando que o ente possa aparecer como tal. Além do terror, há igualmente a presença do pudor, tonalidade afetiva que, nesse caso, passa a ser outro nome para se mostrar o acontecimento apropriador. A Stimmung possibilita a ressignificação do horizonte interpretativo; o pudor dimensiona o seer em sua articulação histórica de aparecimento.

\section{Considerações finais}

No contexto dos anos de 1930, a experiência, que agora não mais se vincula privilegiada e diretamente ao ser-aí, visto que ganha uma roupagem Histórica, é o acontecimento apropriador. O pudor é a tonalidade afetiva que faz com que o seer se essencialize no ente, sendo-lhe muito anterior. É a gratuidade ou dação mesma do seer que faz o ente aparecer, e não mais a revelação de um sentido que o descortina. $O$ pudor não descarta o terror; pelo contrário, este acontecimento apropriador que se articula no pavor resguarda em sua intimidade o terror. A tonalidade afetiva fundamental da retenção é a clareira máxima para a meditação, em especial, do filósofo.

A retenção é a tonalidade afetiva fundamental do filosofar do outro início, uma vez que abre a clareira do seer em sua apropriação histórica, possibilitando o questionamento. E esta apropriação, se tomarmos a história da filosofia como 
exemplo, será marcada pelo encerramento ${ }^{21}$ daquilo que Heidegger chamou de primeiro início. Tal questionamento não é meramente um disputar ou perguntar pura e simplesmente. $O$ questionamento que cede corpo e lugar à retenção e se torna tal tonalidade afetiva fundamental procura imergir no terror do ente que se manifesta em sua inabitualidade, no pavor do ente que se encontra aí e no aí disposto, no desvelamento, na alétheia, na verdade. A tonalidade afetiva fundamental da retenção é o que deve ser suportado, como se escreveu quando se meditava acerca do espanto: o que se suporta é o reconhecimento do ente enquanto tal, bem como o seu desdobramento. Isso nos leva a concluir que suportar a tonalidade afetiva fundamental é o mesmo que a realizar em sua radicalidade, levando-a a termo. Tal fenômeno possibilita questionar a partir da indigência do seer mesmo, já que não-se-sabe-nem-fora-e-nem-dentro. 0 espanto, que deve, portanto, ser suportado, também se expressa como um sofrimento.

Este sofrimento nada tem de psicológico, visto que se refere a um modo distinto de captar o que se revela. É a entrada na prontidão para o seer que igualmente ocorre na esfera de uma escuta atenta. Sofrer, como aqui indicado, é entrar na prontidão para atentar-se com. A retenção é, igualmente, uma tonalidade afetiva que agrega horizontes de outras afecções, como a ausculta, não podendo ser percebida de forma isolada e distante de outras regiões de captação do seer.

Por isso mesmo o captar da tonalidade afetiva fundamental da retenção se deixa perceber como sofrimento, uma vez que dispõe o ser-aí frente ao acontecimento de captar o ente em sua unidade em meio à totalidade. $O$ ente se mostra em sua unidade, o que igualmente faz com que traços do logos também se deixem captar na esfera do desvelamento e verdade do seer. 0 que a retenção deixa e faz aparecer é uma postura para e na direção do ente, de estar e ir ao encontro dele, de residir e deixar habitar em seu desvelar, sendo este comportamento o que Heidegger chamou de téchne (Cf. Heidegger, 2017, p. 227).

\footnotetext{
${ }^{21}$ Esse encerramento deve ser lido como possibilidade de abertura. Será o espanto entendido como tal se assim o tomarmos como encerramento do primeiro início enquanto projeto histórico, porém, que jamais deixará de ser por um legado singular de questionamento, deixando que se possa pensar em um outro início para o pensamento.
} 
A téchne $e^{22}$, por fim, seria a atitude na qual se resguarda a retenção, no sentido de que se desdobra e se fixa, não se devendo entender tal expressão como "técnica", a qual é, segundo Heidegger, objeto e desdobramento da maquinação, mas como o afinar-se e sintonizar-se, estar junto ao ente desvelado em seu essenciar, manifesto em seu seer. A téchne é o ir ao encontro do ente

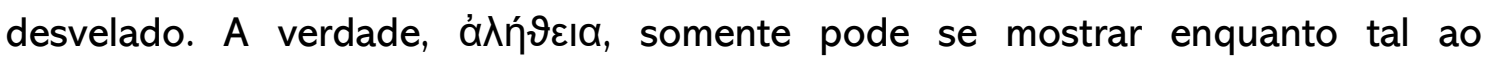
apresentar o ente em seu seer, já a téchne é o que possibilita a imersão propriamente dita no ente.

\section{Referências}

BIEMEL, W. Le concept de monde chez Heidegger. Paris: Laboureur, 1950.

BIRAULT, H. Heidegger et l'expérience de la pensée. Paris: Gallimard, 1978.

DASTUR, F. Heidegger - la question du logos. Paris: Vrin, 2007.

GUMBRECHT, H. U. Atmosfera, ambiência, Stimmung: sobre um potencial oculto da literatura. Trad. Ana Isabel Soares. Rio de Janeiro: Contraponto: Editora PUC Rio, 2014.

2016.

Serenidade, presença e poesia. Trad. Mariana Lage. Belo Horizonte: Relicário,

HAAR, M. Le chant de la terre. Paris: L'Herne, 1987.

Heidegger e a essência do Homem. Trad. Ana Cristina Alves. Lisboa: Instituto Piaget, 1990.

HEIDEGGER, M. A caminho da linguagem. Trad. Márcia Sá Cavalcante Schuback. 4.ed. Petrópolis: Vozes, 2008a.

As questões fundamentais da filosofia ("Problemas" seletos de "lógica"). Trad. Marco Antônio Casanova. São Paulo: Martins Fontes, 2017.

Contribuições à filosofia (Do acontecimento apropriador). Trad. Marco Antônio Casanova. Rio de Janeiro: Via Verita, 2015.

Ensaios e conferências. Trad. Emmanuel Carneiro Leão, Gilvan Fogel, Márcia Sá Cavalcante Schuback. Petrópolis: Vozes, 2001.

. Conferências e escritos filosóficos. Trad. Ernildo Stein. São Paulo: Nova cultual, 1996 (Coleção Os pensadores).

22 Aqui intenta-se apenas chamar a atenção para essa questão. Não se pretende estender sobre um tema tão caro ao segundo movimento de Heidegger, fato que careceria de um novo artigo para tal. 
Hinos de Hölderlin. Trad. Lumir Nahodil. Lisboa: Instituto Piaget, 2004.

Introdução à metafísica. Trad. Emmanuel Carneiro Leão. Rio de Janeiro: Tempo Brasileiro, 1969.

O acontecimento apropriativo. Trad. Marco Antonio Casanova. Rio de Janeiro: Forense Universitária, 2013.

Os conceitos fundamentais da metafísica (mundo - finitude - solidão). Trad. Marco Antônio Casanova. Rio de Janeiro: Forense Universitária, 2006.

$\overline{\text { Piaget, }} 1959$.

Serenidade. Trad. Maria Madalena Andrade e Olga Santos. Lisboa: Instituto $\overline{2008 c}$.

Ser e Tempo. Trad. Márcia Sá Cavalcante Schuback. 3.ed. Petrópolis: Vozes,

SCHNEIDER, P. R. O outro pensar: sobre O que significa pensar? e A época da imagem do mundo, de Heidegger. ljuí: Unijuí, 2005. 